\title{
LEVELS OF STUDENTS' ANXIETY TOWARDS ENGLISH TEACHING THROUGH SONGS
}

\author{
Meliyana Imelda ${ }^{1}$, Junia Fajardini ${ }^{2}$ \\ ${ }^{1}$ IKIP Siliwangi \\ ${ }^{2}$ IKIP Siliwangi \\ ${ }^{1}$ meliyana.imelda@gmail.com, ${ }^{2}$ juniafajardini@gmail.com
}

\begin{abstract}
This study entitled "LEVELS OF STUDENTS' ANXIETY TOWARDS ENGLISH TEACHING THROUGH SONGS" was to observing students' anxiety levels through the songs. In this case, the writers compared levels of students' anxiety in English teaching with songs and English teaching without songs. The participants were two classes consisted 30 students, 15 students from XI Putra and 15 students from XI Putri. The data in this study were collected by giving Foreign Language Classroom Anxiety Scale questionnaire by Horwitz et al (1986). The FLCAS questionnaire consisting of 33 items scoring with Likert's scale and analyzed manually used Oetting's scale to categorize anxiety levels. The study showed that there was a significant difference between class that used English songs method and class without used English songs method. The class with songs was relaxed while the class without songs was mildly anxious.
\end{abstract}

Keywords: Songs, English Songs, Anxiety

\section{INTRODUCTION}

In Indonesia nowadays, English has been taught at schools from the various levels. English is the first foreign language that becomes one of compulsory subject in final examination (UAN). The government prepared the students to be able in communicating with people around the world by mastering English as the international language. The students are expected to keep pace with the development of science and technology by learning English.

According to Nizam, Head of Education Assessment Center, the most significant decrease in the value of subjects is English subjects (Fadhilah, 2017). Why? One of the reasons is students have anxiety in learning English. The students tend to feel shy and not confident when they learn foreign language especially English.

According to (Marsh, 2015) Anxiety is a word we use to describe feelings of unease, worry and fear. The writers describe anxiety is emotions and physical sensations when we are worried, fear, and concern about the future.

To reduce anxiety required special techniques to explain material. One of the techniques is teaching English through songs. According to (Sophya, 2013) song is an authentic source of language. (Sophya, 2013) states that song is a tool to help student in learning English language especially able to increase students' motivation. So, if songs increase students' motivation that mean students have low level of anxiety because they are interesting in learning process. 
According to (Eken, 1996) Teachers use songs in English language classroom for a variety of reasons, the most common being among others are to provide a relaxed classroom atmosphere and to bring variety and fun to teaching and learning

Based on the statement, there are some uses of songs in English teaching. One of them is to provide a relaxed classroom atmosphere. If relaxed classroom atmosphere is created, students will learn better. Another use of songs is to bring variety and fun to teaching and learning. That means songs increase creativity of the teacher in teaching English and make students fun in learning English.

Therefore, the objective of the study is to find out the levels of anxiety experienced by students who are taught English through songs and those who are taught English without songs.

\section{METHOD}

In this research the writers used qualitative research design. According to (Kaswan \& Suprijadi, 2016) A qualitative research design is a research design that place primary importance on studying small samples of purposely chosen individual; not attempting to control contextual factors, but rather seeking, through a variety methods, to understand things from the informants' points of view; and creating a rich and in-depth picture of the phenonema under investigation.

The participants in this research were 30 students from two clases, they were 15 students from XI Putra and 15 students from XI Putri in the academic year 2017/2018.

The data in this study were collected by giving Foreign Language Classroom Anxiety Scale (FLCAS) questionnaire by (Horwitz et al., 1986) and the writers also used observation. There are 33 items questionnaire on the FLCAS. The writers translated the FLCAS into Indonesian language to make the students understand easily.

According to (Mayangta, 2013) FLCAS consist of positive and negative statement. The data were calculated manually with the range of score started from 33 to 165 .

The Likert's scoring scale table to measure students' anxiety level using FLCAS is shown in below.

Table 1. Likert's scoring table stated in (Mayangta, 2013)

\begin{tabular}{cccccc}
\hline Statement & \multicolumn{5}{c}{ Scoring } \\
\cline { 2 - 7 } & $\begin{array}{c}\text { Strongly } \\
\text { Agree }\end{array}$ & Agree & $\begin{array}{c}\text { Neither Agree nor } \\
\text { Disagree }\end{array}$ & Disagree & $\begin{array}{c}\text { Strongly } \\
\text { Disagree }\end{array}$ \\
\hline Positive & 1 & 2 & 3 & 4 & 5 \\
\hline Negative & 5 & 4 & 3 & 2 & 1 \\
\hline
\end{tabular}

As for the categorization of the anxiety level, the research used and adapted Oetting's scale.

Table 2. FLCAS Anxiety Scale adapted from Oetting's Scale (Mayangta, 2013) 


\begin{tabular}{cc}
\hline Range & Level \\
\hline $124-165$ & Very Anxious \\
$108-123$ & Anxious \\
$87-107$ & Mildly Anxious \\
$66-86$ & Relaxed \\
$33-65$ & Very Relaxed \\
\hline
\end{tabular}

\section{RESULTS AND DISCUSSION}

\section{Results}

In this result writers describe and discuss the data of this research based on FLCAS questionnaire and observation. After scoring, writers got the result of analyzing students' anxiety.

Table 3. Result of FLCAS Questionnaire of XI Putra without songs

\begin{tabular}{llc}
\hline No & Students & Total Scores \\
\hline 1 & Student 1 & 117 \\
2 & Student 2 & 112 \\
3 & Student 3 & 101 \\
4 & Student 4 & 77 \\
5 & Student 5 & 127 \\
6 & Student 6 & 83 \\
7 & Student 7 & 55 \\
8 & Student 8 & 105 \\
9 & Student 9 & 77 \\
10 & Student 10 & 97 \\
11 & Student 11 & 111 \\
12 & Student 12 & 96 \\
13 & Student 13 & 99 \\
14 & Student 14 & 95 \\
15 & Student 15 & 72 \\
\hline & Total & $\mathbf{1 , 4 2 4}$ \\
\hline & Average & $\mathbf{9 4 . 9}$ \\
\hline
\end{tabular}

Table 4. Result of FLCAS Questionnaire of XI Putri with songs

\begin{tabular}{llc}
\hline No & Students & Total Scores \\
\hline 1 & Student 1 & 70 \\
2 & Student 2 & 69 \\
3 & Student 3 & 90 \\
4 & Student 4 & 60 \\
5 & Student 5 & 88
\end{tabular}




\begin{tabular}{llc}
6 & Student 6 & 54 \\
7 & Student 7 & 72 \\
8 & Student 8 & 61 \\
9 & Student 9 & 75 \\
10 & Student 10 & 111 \\
11 & Student 11 & 88 \\
12 & Student 12 & 52 \\
13 & Student 13 & 79 \\
14 & Student 14 & 71 \\
15 & Student 15 & 71 \\
\hline & Total & $\mathbf{1 , 1 1 1}$ \\
\hline & Average & $\mathbf{7 4}$ \\
\hline
\end{tabular}

\section{Discussion}

From Table 3 it can be described those students who were taught without songs as follows:

a. Student 1 with score of 117 means they are anxious in learning English.

b. Student 2 with score of 112 means they are anxious in learning English.

c. Student 3 with score of 101 means they are mildly anxious in learning English.

d. Student 4 with score of 77 means they are relaxed in learning English.

e. Student 5 with score of 127 means they are very anxious in learning English.

f. Student 6 with score of 83 means they are relaxed in learning English.

g. Student 7 with score of 55 means they are very relaxed in learning English.

h. Student 8 with score of 105 means they are mildly anxious in learning English.

i. Student 9 with score of 77 means they are relaxed in learning English.

j. Student 10 with score of 97 means they are mildly anxious in learning English.

k. Student 11 with score of 111 means they are anxious in learning English.

1. Student 12 with score of 96 means they are mildly anxious in learning English.

m. Student 13 with score of 99 means they are mildly anxious in learning English.

n. Student 14 with score of 95 means they are mildly anxious in learning English.

o. Student 15 with score of 72 means they are relaxed in learning English.

From Table 3 can also described :

1. $6.67 \%$ of students are very anxious.

2. $20 \%$ of students are anxious.

3. $40 \%$ of students are mildly anxious.

4. $26.67 \%$ of students are relaxed.

5. $6.66 \%$ of students are very relaxed.

Anxiety level mostly experienced by students is mildly anxious (40\%)

From Table 4 it can be described those students who were taught with songs as follows:

a. Student 1 with score of 70 means they are relaxed in learning English.

b. Student 2 with score of 69 means they relaxed in learning English.

c. Student 3 with score of 90 means they are mildly anxious in learning English.

d. Student 4 with score of 60 means they are very relaxed in learning English. 
e. Student 5 with score of 88 means they are mildly anxious in learning English.

f. Student 6 with score of 54 means they are very relaxed in learning English.

g. Student 7 with score of 72 means they are relaxed in learning English.

h. Student 8 with score of 61 means they are very relaxed in learning English.

i. Student 9 with score of 75 means they are relaxed in learning English.

j. Student 10 with score of 111 means they are anxious in learning English.

k. Student 11 with score of 88 means they are mildly anxious in learning English.

1. Student 12 with score of 52 means they are very relaxed in learning English.

m. Student 13 with score of 79 means they are relaxed in learning English.

n. Student 14 with score of 71 means they are relaxed in learning English.

o. Student 15 with score of 71 means they are relaxed in learning English.

From Table 4 can also described :

1. $6.67 \%$ of students are anxious.

2. $20 \%$ of students are mildly anxious.

3. $46.67 \%$ of students are relaxed.

4. $26.66 \%$ of students are very relaxed.

Anxiety level mostly experienced by students is relaxed (46.67\%)

Based on the result of questionnaire above, the writers conclude that there is difference of students' anxiety levels between XI Putra and XI Putri. The average score of XI Putra (without songs) is 94.9 which can be categorized as mildly anxious. And the average score of XI Putri (with songs) is $\mathbf{7 4}$ which can be categorized as relaxed.

\section{CONCLUSION}

Based on the data analysis the writers conclude that:

1. Score of teaching English with songs is 94.9 which can be categorized as mildly anxious

2. Score of teaching English without songs is 74 which can be categorized as relaxed.

\section{ACKNOWLEDGMENTS}

For the first, writers would like to express thanks to The Head Master of SMK Al Yumni Cianjur, for his permission to conduct research. The second is the writers would like to express thanks to our lecturer Mr. Kaswan, S.Pd, M.M for all advices, guidance, and corrections during the completion of this paper. The third is the writers also thank the audiences at template in Professional Journal of English Education (PROJECT), and IKIP Siliwangi supported received for the work.

\section{REFERENCES}

Eken, D. K. (1996) 'Ideas for Using Songs in the English Language Classroom', 34, p. 46. Fadhilah, U. N. (2017) 'Nilai UN SMP Bahasa Indonesia dan Bahasa Inggris Anjlok _ Republika Online'. Available at: https://www.republika.co.id/berita/pendidikan/eduaction/17/06/15/orkzom382-nilai-unsmp-bahasa-indonesia-dan-bahasa-inggris-anjlok.

Horwitz, E. K. et al. (1986) 'Foreign Language Classroom Anxiety', 70(2), pp. 125-132.

Kaswan \& Suprijadi, D. (2016) Research In English Language Education. Bandung: Putra Praktisi. 
Marsh, L. (2015) Understanding Anxiety And Panic Attacks. London: Mind (National Association for Mental Health).

Mayangta, T. (2013) Students' Speaking Anxiety in an EFL Classroom. Universitas Pendidikan Indonesia Press.

Sophya, I. V. (2013) 'Pembelajaran Bahasa Inggris Melalui Lagu Pada Anak Usia Dini’, 1, pp. $1-21$. 